\title{
EVALUATION OF THE PERFORMANCES OF TWO REBS NET RADIOMETER DESIGNS DURING NIMEX AT A TROPICAL SITE IN ILE-IFE, NIGERIA
}

\author{
Sunmonu, L. A. ${ }^{1}$, Ajao, A. I. , Ayoola, M. A. ${ }^{1}$, Ogolo, E. O. ${ }^{2}$, Babatunde, O. A. ${ }^{1}$ \\ and Jegede, $\mathrm{O} . \mathrm{O}^{1}{ }^{1} *$ \\ ${ }^{1}$ Department of Physics and Engineering Physics, Obafemi Awolowo University, Ile-Ife, 220005, Nigeria \\ ${ }^{2}$ Department of Physics, Federal University of Technology, PMB 704 Akure, Nigeria \\ Correspondence to: Lukman A. Sunmonu (niyi.sunmonu@gmail.com; lasunmonu@oauife.edu.ng, +234-806-863-8008)
}

(Received: $19^{\text {th }}$ August, 2019; Accepted: 24 ${ }^{\text {th }}$ May, 2020)

\section{ABSTRACT}

\begin{abstract}
In this study, the performances of two types of Radiation Energy Balance Systems (REBS) net radiometers, a domed (model Q-7.1) and domeless (model NR-LITE) against a reference, four-component net radiometer (model NR01), are evaluated during the conduct of Nigeria Micrometeorological Experiment (NIMEX) held between May 27 and June 12, 2013 at a tropical location in Ile-Ife, Nigeria. During the daytime, net radiation measurements made by NR-LITE and Q-7.1 showed good agreements with NR01, with coefficient of determination for both $>0.90$. The values of the mean and standard deviation for daytime net radiation as measured by NR01, NR-LITE and Q-7.1 were $257.7 \pm 174.7 \mathrm{~W} \mathrm{~m}^{-2}, 179.6 \pm 129.3 \mathrm{~W} \mathrm{~m}^{-2}$ and 240.6 $\pm 153.1 \mathrm{~W} \mathrm{~m}$ ${ }^{2}$, respectively. At nighttime, NR-LITE net radiometer responded to longwave radiation better than Q-7.1. Adjustments made by linear regression of NR-LITE and Q-7.1 datasets with NR01 produced better fit. Though costs of the two REBS type net radiometers are comparatively the same, Q-7.1 performed better than NRLITE. However, for long-term operation, the Q-7.1 type requires periodic (every 2-3 months) changing of the plastic domes due to ageing and cracking, unlike the NR-LITE. So, the NR-LITE is a preferred option to be adopted by the Weather Services in West African countries for routine measurements of net radiation because it does not require periodic changing of the plastic domes.
\end{abstract}

Keywords: Net radiation; REBS net radiometers; 4-component net radiometer; tropical location.

\section{INTRODUCTION}

Accurate and short-period ( $\sim 1$ min.) measurements of net (all-wave) radiation balance is very important to evaluate closure of all the energy fluxes (radiative, sensible, latent and ground heat) at the surface, and to determine the available energy driving the surface-atmosphere energy exchange processes (Foken 2008a).

In West Africa (and is generally true of the tropical areas), manifestations of transient convective clouds during daytime are indicative of short period fluctuations in the values of the net radiation (Jegede et al. 2006; Kothe and Ahrens 2010). As such, for micrometeorological investigations, measurements of absolute values of net radiation demand use of a fast response and accurate sensing system (net radiometers) and efficient datalogging. Presently in the sub-region, short periods (1 min. averages) net radiation data are still very scarce (Ayoola et al. 2014). This problem persists because of the inadequate technical infrastructures and low human capacity within the national meteorological services in the region. Added to this is lack of capacity to deploy, maintain and integrate digital data acquisition systems.

Net radiation at the surface, $R_{N}$ can be determined as algebraic sum of the shortwave $(\sim 0.15-4.0 \mu \mathrm{m})$ and longwave $(3.0-100 \mu \mathrm{m})$ radiation components; given as:

$$
R_{N}=R_{S \downarrow}+R_{S \uparrow}+R_{L \downarrow}+R_{L \uparrow}
$$

where, $R_{N}$ is the net (all-wave) radiation, $R_{s \downarrow}$ is the incoming short-wave (or solar) radiation, $R_{s \uparrow}$ is the outgoing (reflected) short-wave radiation, $R_{L} \downarrow$ is the incoming long-wave (sky) radiation and $R_{L \uparrow}$ is the outgoing (terrestrial) long-wave radiation. Using empirical models, calculations of net radiation determined by magnitudes of the terms appearing in Eq. (1) require dedicated and consistent datasets (Offerle et al. 2003; Jegede et al. 2006; Kjaergaard et al. 2009). This is still a challenge for most areas in West Africa.

Routine measurement of net radiation on component-by-component basis is elaborate and 
expensive to maintain on a long time basis. For the direct measurement of net radiation, basically there are two types of design for net radiometers: an all-wave $(0.25 \mu \mathrm{m}-60 \mu \mathrm{m})$ radiometer or a combination of radiation sensors that measure individual components of the solar (shortwave) and atmospheric (longwave) radiation as shown in Eq. (1) above (see Fritschen and Fritschen 1991; Blonquist et al. 2009).

Several authors (Halldin and Lindroth 1992; Duchon and Wilk 1994; Kustas et al. 1998; Brotzge and Duchon 2000; Cobos and Baker 2003; Blonquist et al. 2009) have evaluated the performances of both types of net radiometers. The integrated net radiometers (commonly known as pyradiometers) are compact and reasonably affordable instrumentation by which measurements of net radiation can be made continuously on a long-term basis (Ayoola et al. 2014). Recent improvements, both in the design and in manufacturing, of pyradiometers show systematic error of less than $10 \%$ of absolute values (Oliver and Wright 1990; Halldin 1991; Foken 2008b). It is highly recommended for micrometeorological investigations that separate measurements of solar and atmospheric radiation components be made for reliable and accurate determination of the value of net radiation (see Halldin and Lindroth 1992; Duchon and Wilk 1994; Kustas et al. 1998; Kohsiek et al. 2007; Foken 2008b; Blonquist et al. 2009). However, the 4component varieties relatively are more expensive (Blonquist et al.2009).

The Q-7.1 net radiometer (manufactured by Radiation and Energy Balance Systems (REBS), Inc., Seattle, WA, USA) is a fairly old sensor since the Campbell Scientific Inc. (CSI), USA commercially introduced it in mid 1990s (it has ceased to be marketed as from 2014). The sensing head is a 60 -junction high output thermopile covered by clear plastic (polyethylene) domes and is unasphyrated (Manual for Q-7.1 net radiometer, 1996). The plastic domes require periodic replacements (2 - 3 months intervals) due to cracking. As such, it requires regular inspection to spot ageing/degradation of the plastic windshields (domes). To prevent dew condensation inside the domes, a dessicator tube is placed in the support frame to keep the air inside dry. The domed sensing head is integrated with a ball joint at its neck to allow for easy adjustment of the spirit level without disturbing the clamps to the mast. The manufacturer provides separate sensitivity factors for the positive and negative values of the net radiation (that is, for the daytime and nighttime conditions). In the case of strong wind conditions $(>5 \mathrm{~m} / \mathrm{s}$ ), a correction factor is provided to compensate for convective cooling of the detector surface. Application of this correction is not tangible at Ile-Ife in the sense that low wind regime persists (the mean wind speed is less than $1.5 \mathrm{~m} / \mathrm{s}$ ). A specification for the Q-7.1 net radiometer is listed in the Table 1.

The NR-LITE net radiometer is a domeless-type manufactured by Kipp \& Zonen B.V., Delft, Netherlands and marketed by CSI. The year of its introduction was ca. 2003 and currently, it has been replaced by the NR-LITE2, retaining essentially the same design as the previous model. The sensor is a thin thermopile with slightly cone shaped, up- and down-ward looking surfaces. It is relatively easy to maintain (cleaning-wise) because the sensor surface is coated with Teflon. Therefore, it is suitable for relatively long term unattended operations. The slim design of the sensor head ensures minimal radiative heat loss and thermal convection (Manual for NR-LITE net radiometer 2006). The flattened top and bottom surfaces make for improved cosine response. The manufacturer supplies a sensitivity factor for both positive and negative measurements of net radiation by the sensor. An equation is provided to correct for the measurement errors (adjustment) occasioned by the sensitivity of the sensor to the high wind speeds. The NR-LITE is slightly less accurate than the more traditional type net radiometers which use plastic domes due to the Teflon coating of its sensor surface (Manual for NR-LITE net radiometer, 2006). Details of the NR-LITE net radiometer are contained in Table 1. 
Table 1: Specifications sheet for NR-LITE, Q-7.1 and NR01 (4-component type) net radiometers.

\begin{tabular}{|c|c|c|c|c|c|c|}
\hline $\begin{array}{l}\text { Model/Type of } \\
\text { Net Radiometer }\end{array}$ & $\begin{array}{c}\text { Costs } \\
\text { (approx. }\end{array}$ & Sensitivity/Accuracy & $\begin{array}{l}\text { Response } \\
\text { time (s) }\end{array}$ & Scrial No. & $\begin{array}{c}{ }^{+} \text {Response to } \\
\text { SW }(0.2-1.0 \\
{[\mathrm{fm})}\end{array}$ & $\begin{array}{c}{ }^{+} \text {Response to } \\
\text { LW }(1.0-100 \\
\mu \mathrm{m})\end{array}$ \\
\hline $\begin{array}{l}\text { Q-7.1 (REBS) } \\
\text { Campbell } \\
\text { Scientific }\end{array}$ & $\$ 1200$ & $\begin{array}{l}9.6 \mathrm{Wm} / \mathrm{mV} \text { (+ve } \\
\text { values); } 11.9 \mathrm{Wm} \\
2 / \mathrm{mV} \text { (-ve values) }\end{array}$ & $\sim 30$ & Q94193 & good & poor \\
\hline $\begin{array}{l}\text { NR-LITE (REBS) } \\
\text { Hukscflux }\end{array}$ & $\$ 1600$ & $14.00 \mu \mathrm{rV} / \mathrm{Wm}{ }^{3}$ & $\sim 30$ & 093242 & good & good \\
\hline $\begin{array}{l}\text { NR01 (4- } \\
\text { component) } \\
\text { Hukseflux }\end{array}$ & $\$ 4200$ & $\begin{array}{c}\text { SR01-Up } \\
\left(15.5 \mu \mathrm{V} / \mathrm{Wm}^{-2}\right) \& \\
\text { SRD1-Down }\{15.6 \\
\left.\mu V / W \mathrm{~m}^{-2}\right) . \text { IR01-Up } \\
\left\{9.9 \mathrm{~V} / \mathrm{Wm}^{2}\right) ; \text { IRO1- } \\
\text { Down }\left(8.2 \mu \mathrm{V} / \mathrm{Wm}^{\prime}\right\}\end{array}$ & 18 & 1182 & good & Very good \\
\hline
\end{tabular}

In the present study, two different designs of commercially available REBS type net radiometers described above: one with polystyrene domes (model Q-7.1) and another, domeless (model NR-LITE), were set up in the field. Measurements with these instruments were compared to that made by the four-component net radiometer, model NR01, chosen as the reference. The aim of the field study was to determine which of the two REBS types of net radiometers (domed and domeless) has better accuracy and performance. Another objective was to test the reliability of integrated (all-wave) net radiometers in use in West Africa.

Net radiation measurements at the NIMEX site

The Nigeria Micrometeorological Experiments (NIMEX) is a series of field investigations of the mean and turbulent characteristics of atmospheric surface layer conducted at selected sites in Obafemi Awolowo University campus, Ile-
Ife, Nigeria (Jegede et al. 2004). Ile-Ife is in the "tropical wet and dry" zone of West A frica with an annual average rainfall between 1000 and 1500 $\mathrm{mm}$. The NIMEX research, which started in 2004, has as objectives determination of balance of the surface energy fluxes (radiative, sensible, latent and ground heat) at the land-surface atmosphere at a tropical location.

As part of NIMEX project held in May/June 2013, surface radiation energy balance system comprising of three net radiometers: NR01, NRLITE and Q-7.1, respectively, were set up at measurement site $\left(7.52^{\circ} \mathrm{N}, 4.52^{\circ} \mathrm{E}\right)$ near the main bowl of the University sports complex. Arrangement of the radiation balance instrumentation on site is shown in the Fig. 1. Colocated within the same study area were the eddy covariance (EC) and Bowen ratio energy balance (BREB) systems. In addition, weather conditions observed during the period of study were recorded. 


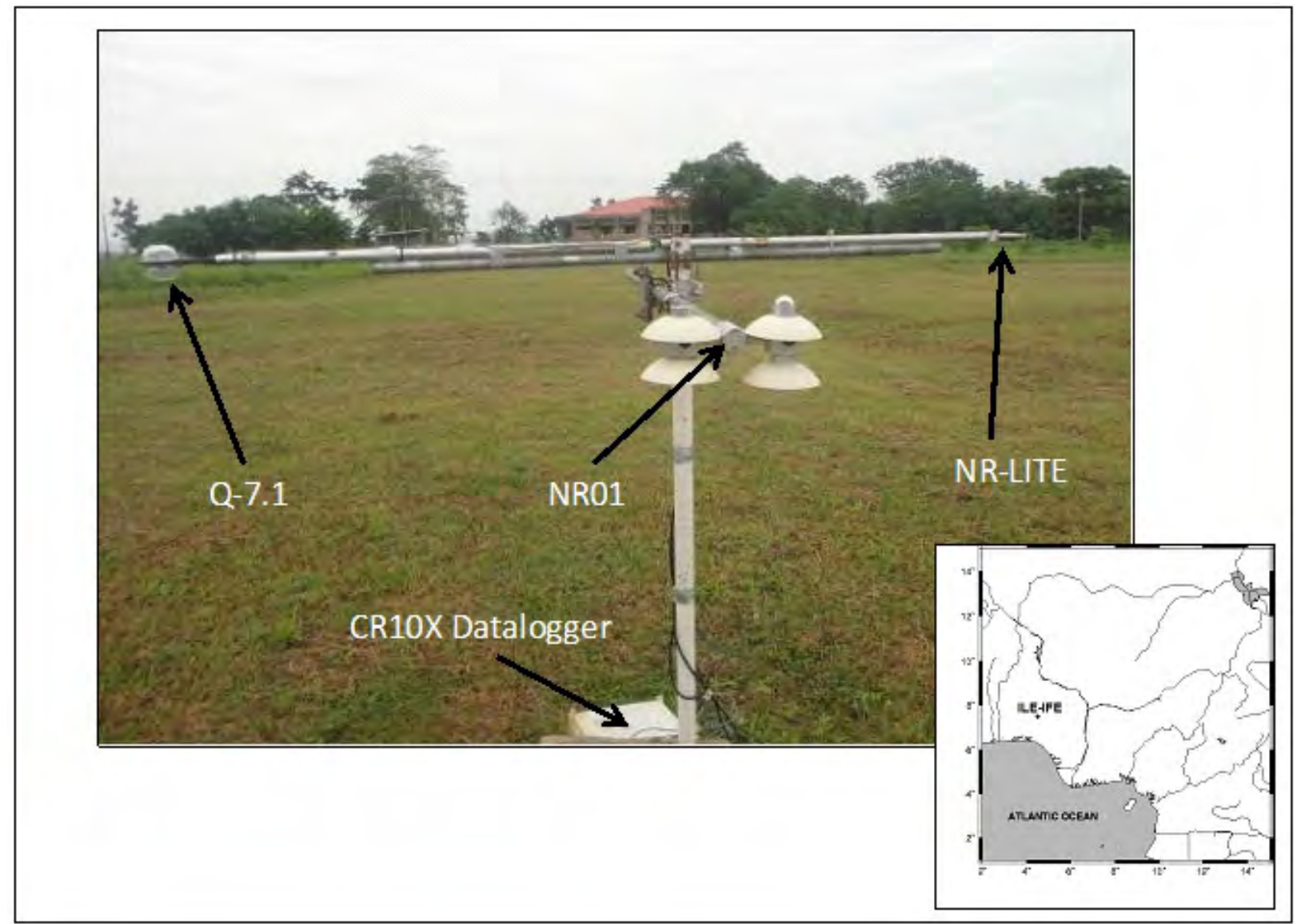

Figure 1: Arrangement of net radiometers (NR01, NR-LITE and Q-7.1) at the measurement site near the Sports Complex of Obafemi Awolowo University (OAU), Ile-Ife, Nigeria. In the insert is the map of Nigeria showing Ile-Ife $\left(7.52^{\circ} \mathrm{N}, 4.52^{\circ}\right.$ E).

The period while the radiation measurement was taken among other meteorological parameters is May $27^{\text {th }}$ to June $12^{\text {th }}, 2013$. The general weather pattern showed cloudy-sky conditions in daytime and devoid of appreciable precipitation despite being the peak of the rainy season in Ile-Ife. In the same period of observation, the atmospheric condition was warm and humid with the daily ranges for air temperature and relative humidity recorded as $22^{\circ} \mathrm{C}-37.4^{\circ} \mathrm{C}$ and $46.2 \%-95.8 \%$, respectively. For the period, the wind speed was low and the mean value ranged between $1.0 \mathrm{~ms}^{-1}$ and $1.8 \mathrm{~ms}^{-1}$. The daily average of global radiation at the surface ranged between $110.0 \mathrm{~W} \mathrm{~m}^{-2}$ and 224.3 $\mathrm{W} \mathrm{m}^{-2}$. The measurement surface was shortgrass $(\leq 5 \mathrm{~cm})$ and the albedo, $a$, was 0.21 . The weather summary is detailed in Table 2 . 
Table 2: Meteorological variables recorded at the measurement site in Ile-Ife $\left(7.52^{\circ} \mathrm{N}, 4.52^{\circ} \mathrm{E}\right)$ during the observation period, May $29^{\text {th }}$ to June $9^{\text {th }}, 2013$ (DOY 149 - DOY 160).

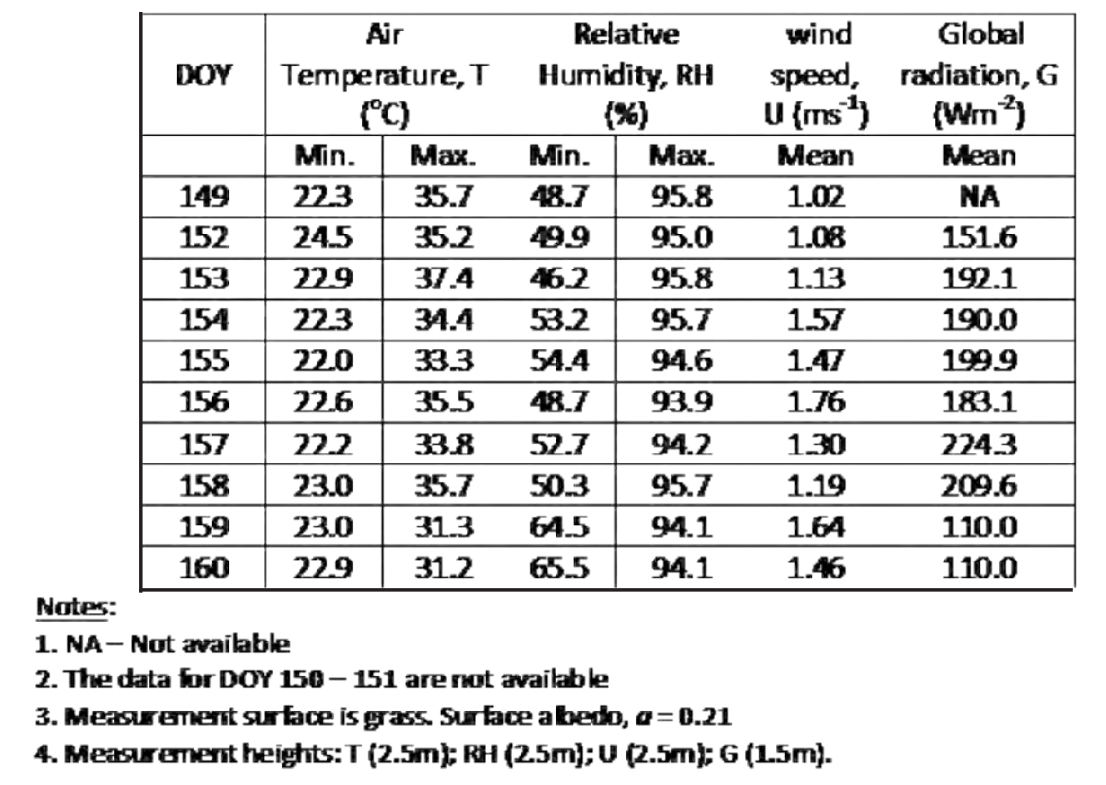

The three net radiometers were placed at the same height of $1.5 \mathrm{~m}$ above grass surface. Orientation of the net radiometers was a T-like formation (see Fig. 1), with the NR01 being in the middle position and facing the north direction. The Q-7.1 and NRLITE were oriented in east-west direction. The siting of the net radiometers was distant from tall trees, structures and buildings, so as to prevent shadows falling on the sensors. With the aid of integrated spirit level on the housing of the net radiometers, careful adjustments of the sensing heads were done to ensure proper alignment with the horizontal. Every morning, the top and bottom surfaces were cleaned with soft brush and lint-free cloth to remove the fine dust particles settling on the sensing heads.

For Q-7.1 net radiometer, the sensitivities for positive and negative values of net radiation were $9.60 \mathrm{~W} \mathrm{~m}^{-2} / \mathrm{mV}$ and $11.90 \mathrm{~W} \mathrm{~m}^{-2} / \mathrm{mV}$, respectively. The sensitivity quoted for NR-LITE net radiometer was $14.00 \square \mu \mathrm{V} / \mathrm{W} \mathrm{m}^{-2}$. In the case of NR01, the sensitivities for the top and bottom pyranometers (SR01) were $15.50 \mu \mathrm{V} / \mathrm{W} \mathrm{m}{ }^{-2}$ and $15.60 \mu \mathrm{V} / \mathrm{W} \mathrm{m}^{-2}$, respectively. The sensitivities of the two pyrgeometers (IR01), were $9.90 \mu \mathrm{V} / \mathrm{W} \mathrm{m}^{-2}$ and $8.20 \mu \mathrm{V} / \mathrm{W} \mathrm{m} \mathrm{m}^{-2}$, for top and bottom sensors respectively (specifications of the net radiometers are contained in the Table 1).

The net radiometers were connected to a datalogger (Campbell Scientific, CR10X) and programmed using LOGGERNET ${ }^{\circledR}$ software for data acquisition. The data were sampled every 10 secs. and stored as 2-min. averages. Once daily, the data, which is stored in the logger memory, was collected by a portable computer for further processing. The net radiation data was screened for erroneous values due to the instrument malfunctioning (electrical spikes) or out-of-range measurement values were flagged off. Stringent QA/QC procedure was introduced to remove spurious data.

The net radiation data acquired by NR01 (chosen as reference) was compared to measurements obtained both by NR-LITE and Q-7.1 net radiometers. For the comparison, two quantitative parameters $B L A S$ and DIFF defined below as;

$$
\begin{aligned}
& \text { BIAS }=\frac{\sum_{i}\left|R_{N R 01, i}-R_{R E B S, i}\right|}{N} \\
& D I F F=\frac{\sum_{i}\left(R_{N R 01, i}-R_{R E B S, i}\right)}{N}
\end{aligned}
$$

were chosen to test the goodness of fit for the 
data. In Eqs. (2) $R_{\mathrm{NR} 01, i}$ and $R_{\mathrm{REBS}, i}$ respectively represent net radiation data values as measured by NR01 net radiometer and the REBS (i.e., Q-7.1 and NR-LITE) net radiometers. $N$ is the total number of the data points. Linear regression of the measured data by REBS net radiometers with NR01 net radiometer was performed using data analysis software, MicroCal Origin ${ }^{\circledR}$. The net radiation data acquired for this study covered the period beginning from May $27^{\text {th }}$ to June $12^{\text {th }}, 2013$ (DOY 147-163).

\section{RESULTS AND DISCUSSION}

Two-minute averages (as time series) of net radiation at the study site in Ile-Ife showing the diurnal course for the three net radiometers, Q7.1, NR-LITE and NR01, are plotted in Fig. 2 for the measurement period May $27^{\text {th }}$ to June $12^{\text {th }}$ 2013. A specific day, May 29 $9^{\text {th }}, 2013$ (DOY 149) shown in Fig. 3 showed detailed diurnal variation for the three net radiometers. In both figures, the diurnal trends obtained for the three net radiation sensors are similar, both in magnitudes and tendencies. Generally, measurements made with both NR-LITE and Q-7.1 net radiometers were found to show good agreement with values obtained by NR01 net radiometer.

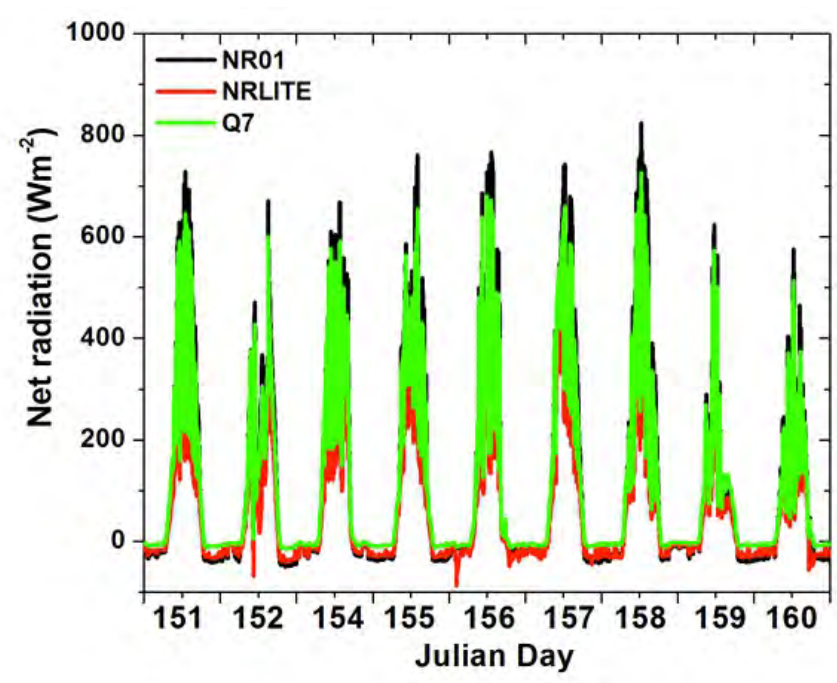

Figure 2: Diurnal variation of net radiation measurements with NR01 (4-component type), NR-LITE and Q-7.1 net radiometers at the measurement site for the period $27^{\text {th }}$ May $-12^{\text {th }}$ June 2013.

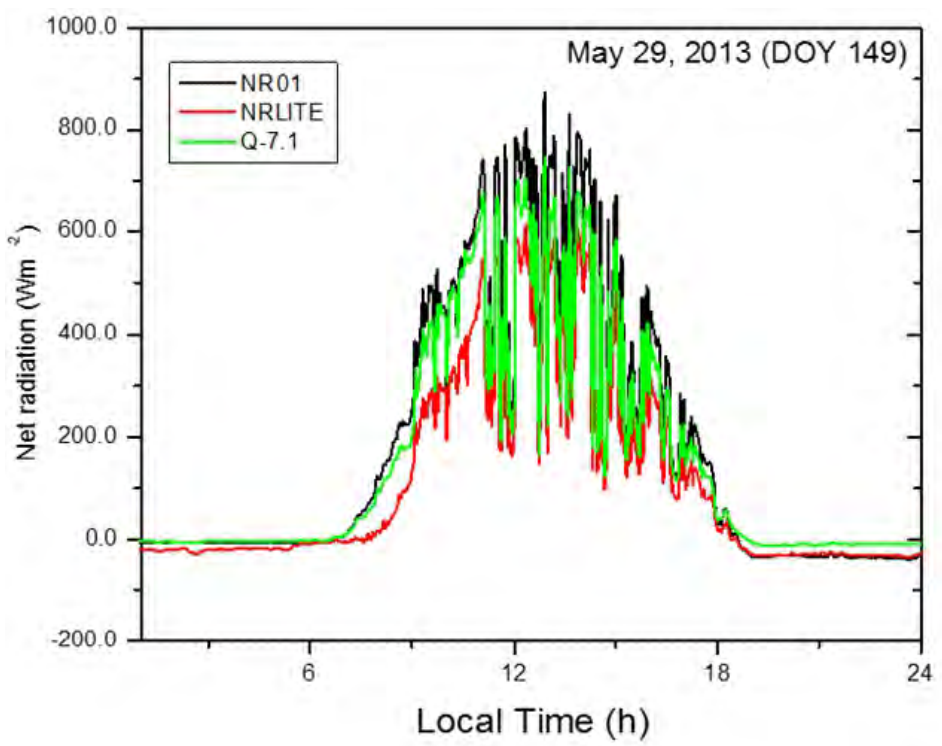

Figure 3: Diurnal variation of net radiation measurements with NR01 (4-component type), NR-LITE and Q-7.1 net radiometers at the measurement site on $29^{\text {th }}$ May 2013 (DOY 149). 
For daytime conditions when $R_{N}>0$, the values of net radiation measured by the REBS net radiometers (Q-7.1 and NR-LITE) were found to be lower than those obtained by NR01. The percentage errors in the values obtained for Q-7.1 and NR-LITE net radiometers were respectively (0-30\%) and (10-50\%) lower than for NR01. The maximum daytime values of net radiation measured by NR01 was $872.0 \mathrm{~W} \mathrm{~m}^{-2}$ at about 13:00 $h$. and this was the highest value of the three net radiometers compared. At the same time, the corresponding values of net radiation for Q-7.1 and NR-LITE were $747.0 \mathrm{~W} \mathrm{~m}^{-2}$ and $645.3 \mathrm{~W} \mathrm{~m}^{-2}$ respectively. For nighttime periods, the NR-LITE net radiometer performed better than Q-7.1. The performance by Q-7.1 sensor is found to be poor at nighttime, which suggests that the net radiometer does not show a good sensitivity in the longwave bands (Manual for Q-7.1 net radiometer, 1996).
Comparison of measurements of net radiation by Q-7.1 and NR-LITE with NR01 (reference sensor) for the observation period, June $1^{\text {st }}$ to $9^{\text {th }}$, 2013 (DOY 152 - 160) are shown as scatter plots in Figs. 4 and 5 for daytime $\left(R_{N}>0\right)$ and nighttime $\left(R_{N}<0\right)$ conditions respectively. The 1:1 line drawn and linear regression relationships were obtained to compare the values of domed and domeless-type net radiometers with NR01. In daytime cases plotted in Figs. 4(a)-(i), it is observed that measurements by Q-7.1 net radiometer compared more favorably to benchmark values of NR01 than values obtained from NR-LITE. The dispersion and outliers in NR-LITE data were worse than what was obtained from Q-7.1 values, which is similar to the observations made by Brotzge and Duchon (2000) and Blonquist et al. (2009). This resulted in lower means and standard deviation in NR-LITE values when compared to NR01 values.
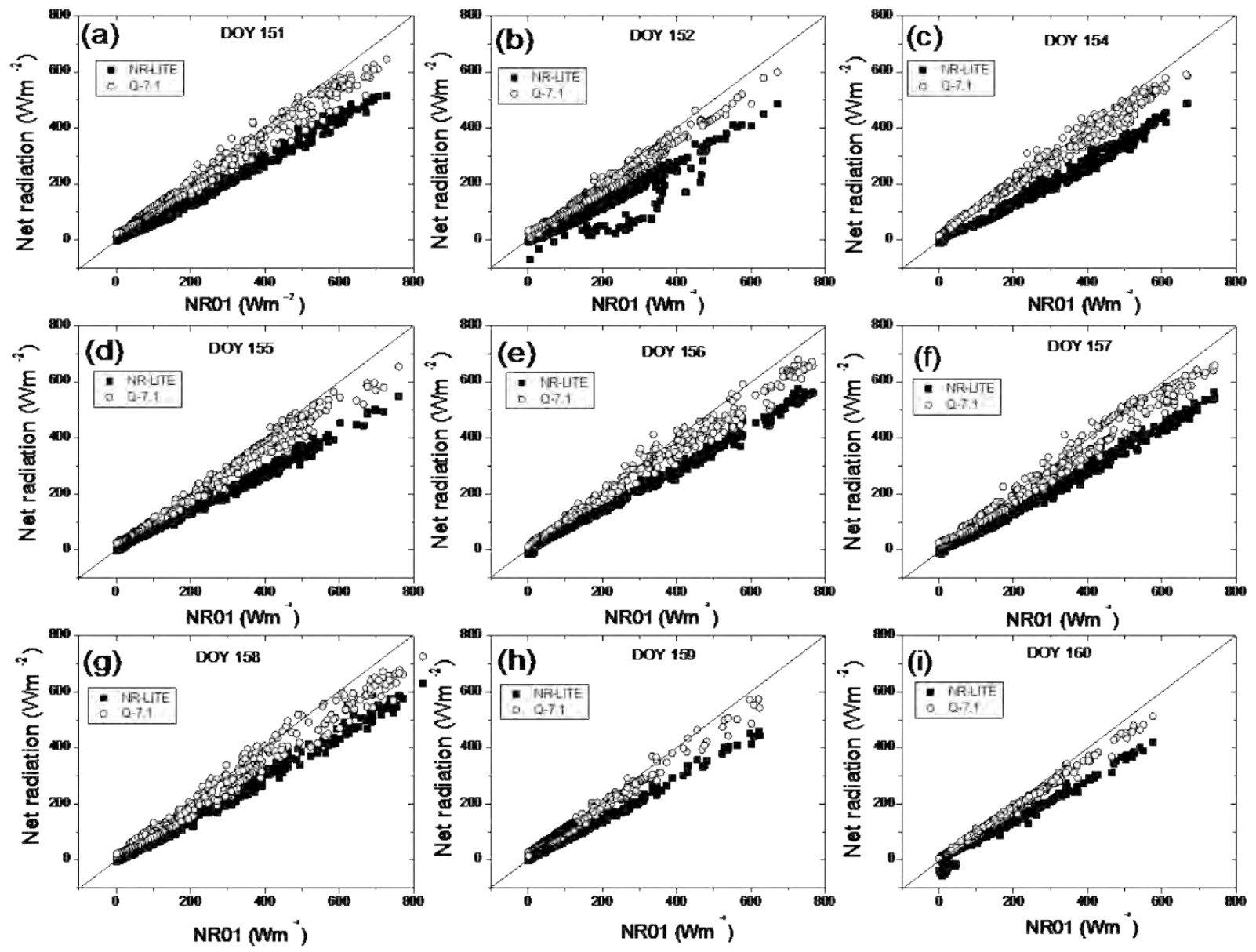

Figure 4: Scatter plots of net radiation measurements for NR-LITE and Q-7.1 net radiometers with NR01 (as reference) for the period: May $31^{\text {st }}-$ June $9^{\text {th }}, 2013$ (DOY $151-$ DOY 160) during daytime $\left(R_{N}>0\right)$. 

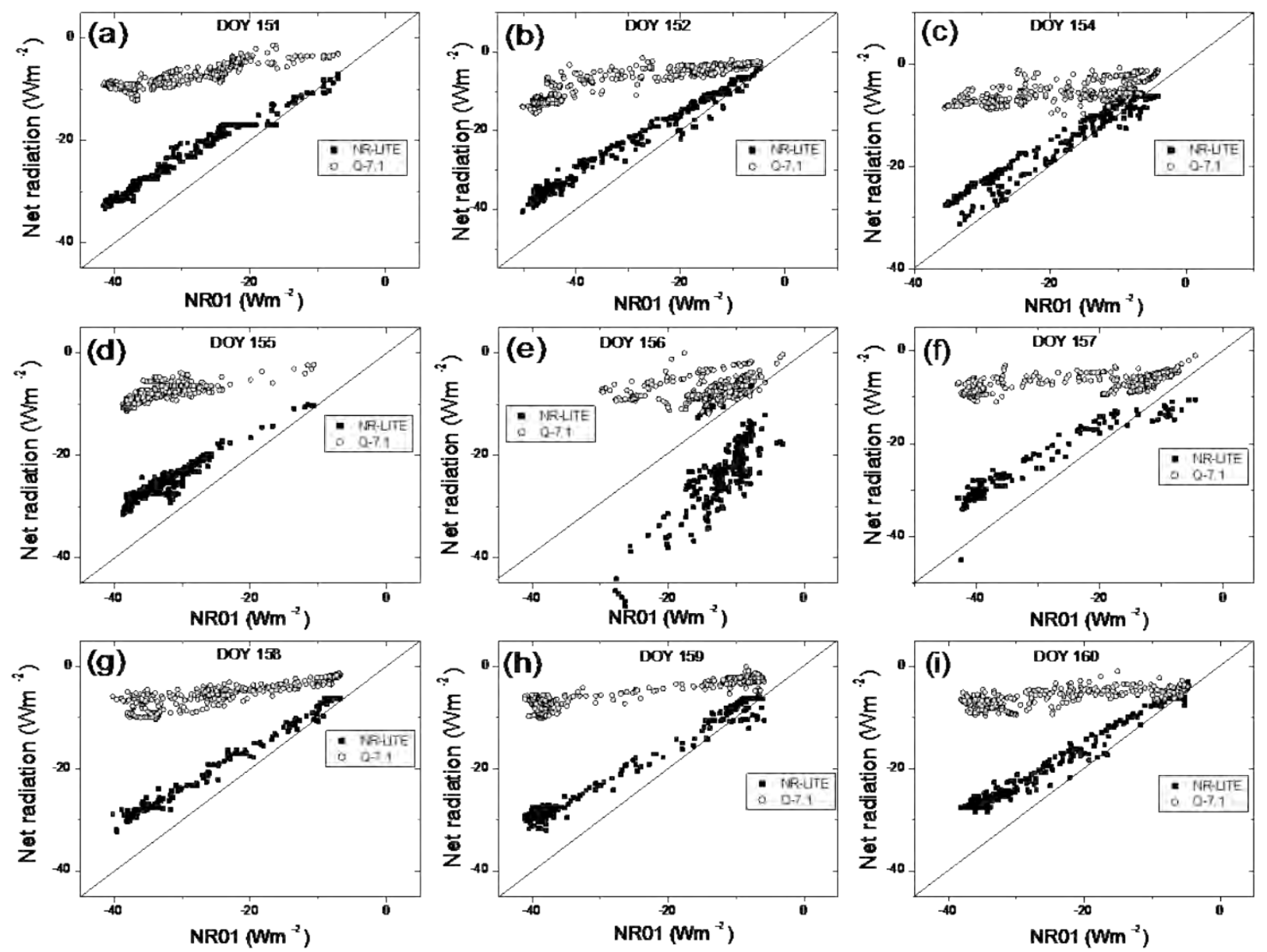

Figure 5: Scatter plots of net radiation measurements for NR-LITE and Q-7.1 net radiometers with NR01 (as reference) on May $31^{\text {st }}$ - June $9^{\text {th }}, 2013$ (DOY $151-$ DOY 160) during nighttime $\left(R_{N}<0\right)$.

For nighttime conditions shown in Figs. 5(a)-(i), the scatter was worse than the daytime for both NR-LITE and Q-7.1. The Q-7.1 data does not show a significant correlation to the NR01.

Fig. 6 shows the scatter plots of residuals of net radiation measurements for $(a)$ NR-LITE and $(b)$ Q-7.1 net radiometers for the period of May $31^{\text {st }}-$
June $9^{\text {th }}, 2013$ (DOY 151 - DOY 160) during nighttime conditions. The coefficient of determination, $R^{2}$ for the residual of NR-LITE was 0.9639 while that of Q-7.1 was 0.6972. This reinforced the fact that, during the nighttime conditions, NR-LITE closely mirrored the reference measurement of NR01 than Q-7.1 net radiometer. 


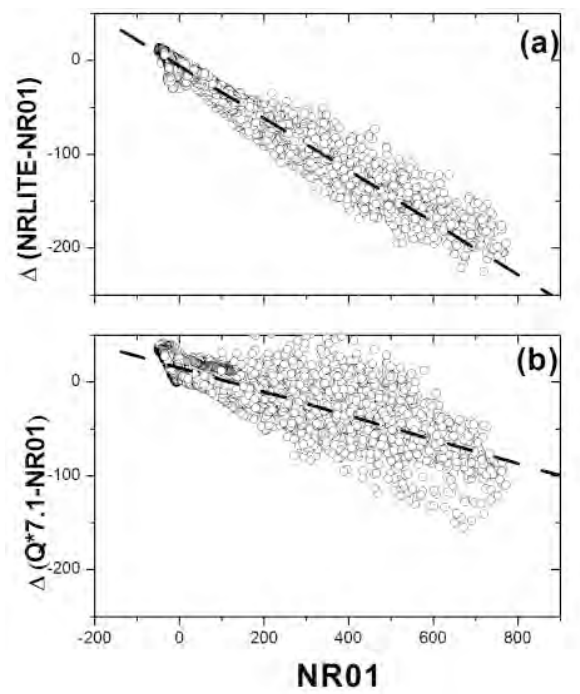

Figure 6: Scatter plots of residuals of net radiation measurements for (a) NR-LITE and (b) Q-7.1 net radiometers for the period: May $31^{\text {st }}$ - June $9^{\text {th }}, 2013$ (DOY 151 - DOY 160) under nighttime conditions.

For daytime $\left(\mathrm{R}_{\mathrm{N}}>0\right)$ and nighttime $\left(\mathrm{R}_{\mathrm{N}}<0\right)$ conditions, computed statistical measures of DIFF and BLAS (as defined in Eqs. (2) and (3) above) and the mean values with their respective standard deviations from the net radiation dataset (2-min. averages for DOY 151 to DOY 160) are given in the Tables 3 and 4 . In daytimes (see Table 3 ), the mean value of net radiation obtained by Q7.1 net radiometer $\left(240.6 \pm 153.1 \mathrm{~W} \mathrm{~m}^{-2}\right)$ compared better to NR01 value $(257.7 \pm 174.7 \mathrm{~W}$ $\left.\mathrm{m}^{-2}\right)$ than NR-LITE value $\left(179.6 \pm 129.3 \mathrm{~W} \mathrm{~m}^{-2}\right)$. This then suggests that Q-7.1 values have smaller dispersion than NR-LITE when compared with the NR01 dataset during daytime conditions. The statistical measures, DIFF and BLAS given in the same Table 3 for the NR-LITE net radiometer were the same value $78.11 \mathrm{~W} \mathrm{~m}^{-2}$, while for the Q7.1 net radiometer, these values estimated were 17.09 $\mathrm{W} \mathrm{m}^{-2}$ and $25.96 \mathrm{~W} \mathrm{~m}^{-2}$ respectively. The lower BIAS and DIFF obtained for Q-7.1 values clearly indicate a lower departure from the mean benchmark values. These measures (DIFF and
$B I A S)$ quantitatively showed that the performance of Q-7.1 was better than NR-LITE for net radiation measurement during daytime condition.

In Table 4 obtained for nighttime conditions $\left(R_{N}\right.$ $<0$ ), it is observed that net radiation values measured by NR-LITE net radiometer have better agreement with the NR01 compared to Q-7.1 net radiometer. This observation is in agreement with the findings made by Samani et al. (2005) and Blonquist et al. (2009). The mean value obtained by NR-LITE was $-21.4 \pm 8.0 \mathrm{~W} \mathrm{~m}^{-2}$, while that of Q-7.1 was $-6.5 \pm 2.3 \mathrm{~W} \mathrm{~m}^{-2}$. For NR01, the mean value was $-25.3 \pm 10.1 \mathrm{~W} \mathrm{~m}^{-2}$. The DIFF and BIAS for the NR-LITE were $-3.88 \mathrm{~W} \mathrm{~m}^{-2}$ and $6.51 \mathrm{~W} \mathrm{~m}^{-2}$ respectively, while these values for the Q-7.1 were $-17.56 \mathrm{~W} \mathrm{~m}^{-2}$ and 17.56 $\mathrm{W} \mathrm{m}^{-2}$ respectively. The larger DIFF and BIAS value reported for Q-7.1 measurements indicate significant deviation from NR01 values suggesting that its performance at nighttime was inconsistent and poor. 
Table 3: Statistical measures of mean, standard deviation, DIFF and BLAS for NR-LITE and Q-7.1 net radiometers with NR01 (reference net radiometer) determined for the observation period: May 31 to June $9^{\text {th }}, 2013$ (DOY 151 - DOY 160) for daytime $\left(R_{N}>0\right)$.

\begin{tabular}{|c|c|c|c|c|c|c|c|}
\hline \multirow{2}{*}{ DOY } & NR01 & \multicolumn{3}{|c|}{ NR-LITE } & \multicolumn{3}{|c|}{ Q-7.1 } \\
\hline & $\begin{array}{c}\text { Mean } \pm \text { SD } \\
\left(W^{-2}\right)\end{array}$ & $\begin{array}{c}\operatorname{Mean} \pm S D \\
\left(\mathrm{Wm}^{-2}\right)\end{array}$ & $\begin{array}{l}\text { DIFF } \\
\left(\mathrm{Wm}^{-2}\right)\end{array}$ & $\begin{array}{l}\text { BIAS } \\
\left(\mathrm{Wm}^{-2}\right)\end{array}$ & $\begin{array}{c}\text { Mean } \pm \text { SD } \\
\left(\mathbf{W m}^{-2}\right)\end{array}$ & $\begin{array}{c}\text { DIFF } \\
\left(\mathrm{Wm}^{-2}\right)\end{array}$ & $\begin{array}{l}\text { BIAS } \\
\left(\mathrm{Wm}^{-2}\right)\end{array}$ \\
\hline 151 & $289.0 \pm 196$ & $2028 \pm 1461$ & 8620 & 8620 & $2714 \pm 1723$ & 17.63 & 2857 \\
\hline 152 & $214.0 \pm 140.6$ & $140.7 \pm 99.6$ & 73.10 & 73.10 & $199.0 \pm 120.7$ & 1493 & 2126 \\
\hline 154 & $304.0 \pm 1715$ & $2064 \pm 123.6$ & 97.60 & 97.6 & $288.5 \pm 150.1$ & $15 \_40$ & 28.10 \\
\hline 155 & $289.1 \pm 1762$ & $199.6 \pm 1243$ & 89.40 & 89.4 & $2686 \pm 153.7$ & 2050 & 27.20 \\
\hline 156 & $284.4 \pm 230.4$ & $2043 \pm 1707$ & 80.10 & 80.1 & $2633 \pm 1992$ & 2110 & 3120 \\
\hline 157 & $329-4 \pm 200-7$ & $233.0 \pm 1517$ & 96.40 & 964 & $306.0 \pm 182.8$ & 2330 & 3140 \\
\hline 158 & $302.0 \pm 213 \_1$ & $219.0 \pm 164.1$ & 83.04 & 83.04 & $274.9 \pm 186.1$ & 27.10 & 34.15 \\
\hline 159 & $1495 \pm 120.0$ & $105.4 \pm 87.8$ & 44.14 & 44.14 & $1502 \pm 103.6$ & $-0.6 \theta$ & 1614 \\
\hline 160 & $1579 \pm 1239$ & $1049 \pm 95.7$ & 5298 & 5298 & $1433 \pm 109.7$ & 14.57 & 15.61 \\
\hline $\begin{array}{l}\text { Period } \\
\text { Means }\end{array}$ & $257_{-} 7 \pm 174.7$ & $179.6 \pm 1293$ & 78.11 & 78.11 & $240.6 \pm 153.1$ & 17.09 & 2596 \\
\hline
\end{tabular}

Table 4: Statistical measures of mean, standard deviation, DIFF and BLAS for NR-LITE and Q-7.1 net radiometers with NR01 (reference net radiometer) determined for the observation period: May $31^{\text {st }}$ to June $9^{\text {th }}$, 2013 (DOY 151 - DOY 160) for nighttime $\left(R_{N}<0\right)$.

\begin{tabular}{|c|c|c|c|c|c|c|c|}
\hline \multirow{2}{*}{ DOY } & NR01 & \multicolumn{3}{|c|}{ NRLITE } & \multicolumn{3}{|c|}{ Q-7.1 } \\
\hline & $\begin{array}{c}\operatorname{Mean} \pm \text { SD } \\
\left(\mathrm{Wm}^{-2}\right)\end{array}$ & $\begin{array}{c}\operatorname{Mean} \pm \text { SD } \\
\left(\mathrm{Wm}^{-2}\right)\end{array}$ & $\begin{array}{l}\text { DIFF } \\
\left(\mathrm{Wm}^{-2}\right)\end{array}$ & $\begin{array}{l}\text { BIAS } \\
\left(\mathrm{Wm}^{-2}\right)\end{array}$ & $\begin{array}{c}\operatorname{Mean} \pm S D \\
\left(W^{-2}\right)\end{array}$ & $\begin{array}{c}\text { DIFF } \\
\left(\mathrm{Wm}^{-2}\right)\end{array}$ & $\begin{array}{c}\text { BIAS } \\
\left(\mathrm{Wm}^{-2}\right)\end{array}$ \\
\hline 151 & $-29.4 \pm 8.7$ & $-23.1 \pm 6.7$ & -6.28 & 6.33 & $-73 \pm 22$ & -2201 & 22.01 \\
\hline 152 & $-30.7 \pm 15.4$ & $-241 \pm 11.8$ & -6.55 & 6.66 & $-79 \pm 41$ & -2290 & 2290 \\
\hline 154 & $-18.0 \pm 9.8$ & $-15.0 \pm 7.7$ & -3.00 & 3.43 & $-53 \pm 23$ & -1299 & 1299 \\
\hline 155 & $-33.7 \pm 4.8$ & $-262 \pm 3.6$ & -7.48 & 7.48 & $-8.1 \pm 17$ & -2559 & 2559 \\
\hline 156 & $-121 \pm 42$ & $-229 \pm 7.6$ & 10.78 & 1118 & $-6.8 \pm 21$ & -6.84 & 6.84 \\
\hline 157 & $-320 \pm 11.0$ & $-25.4 \pm 7.2$ & -659 & 7.49 & $-6.8 \pm 18$ & -1494 & 1494 \\
\hline 158 & $-220 \pm 122$ & $-17.6 \pm 9.6$ & -4.44 & 4.45 & $-5.1 \pm 24$ & -17.47 & 17.47 \\
\hline 159 & $-225 \pm 14.1$ & $-173 \pm 102$ & -5.22 & 534 & $-4.7 \pm 26$ & -1647 & 16.47 \\
\hline 160 & $-27.1 \pm 103$ & $-209 \pm 7.6$ & -6.15 & 622 & $-6.1 \pm 17$ & -18.82 & 18.82 \\
\hline Period Means & $-253 \pm 10.1$ & $-214 \pm 8.0$ & -3.88 & 651 & $-65 \pm 23$ & $-17 \leq 6$ & 1756 \\
\hline
\end{tabular}



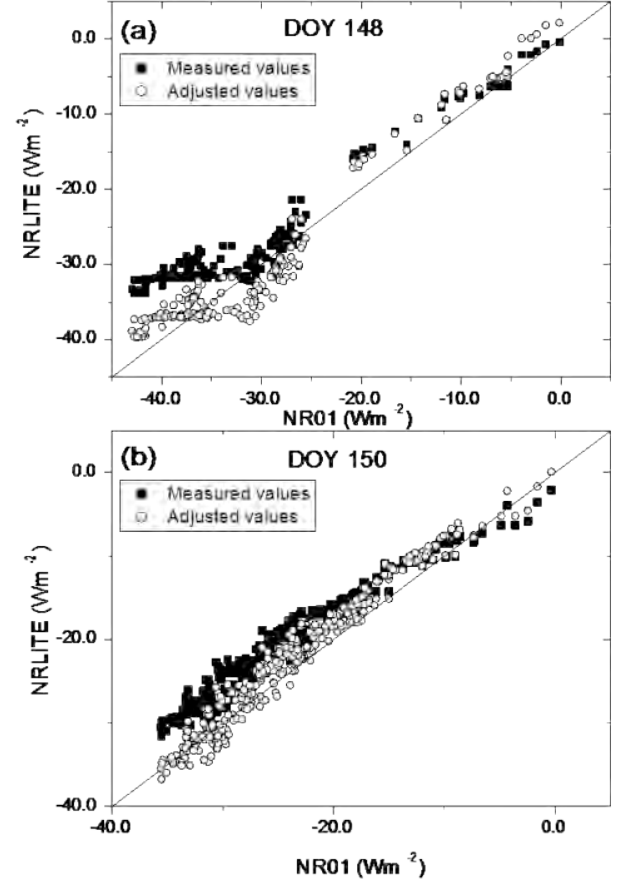

Figure 8: Scatter plots of measured and adjusted values of net radiation for (a) NR-LITE net radiometer with NR01 on May $28^{\text {th }}, 2013$ (DOY 148) for nighttime. Figure 8(b) same as DOY 148, but for DOY 150.
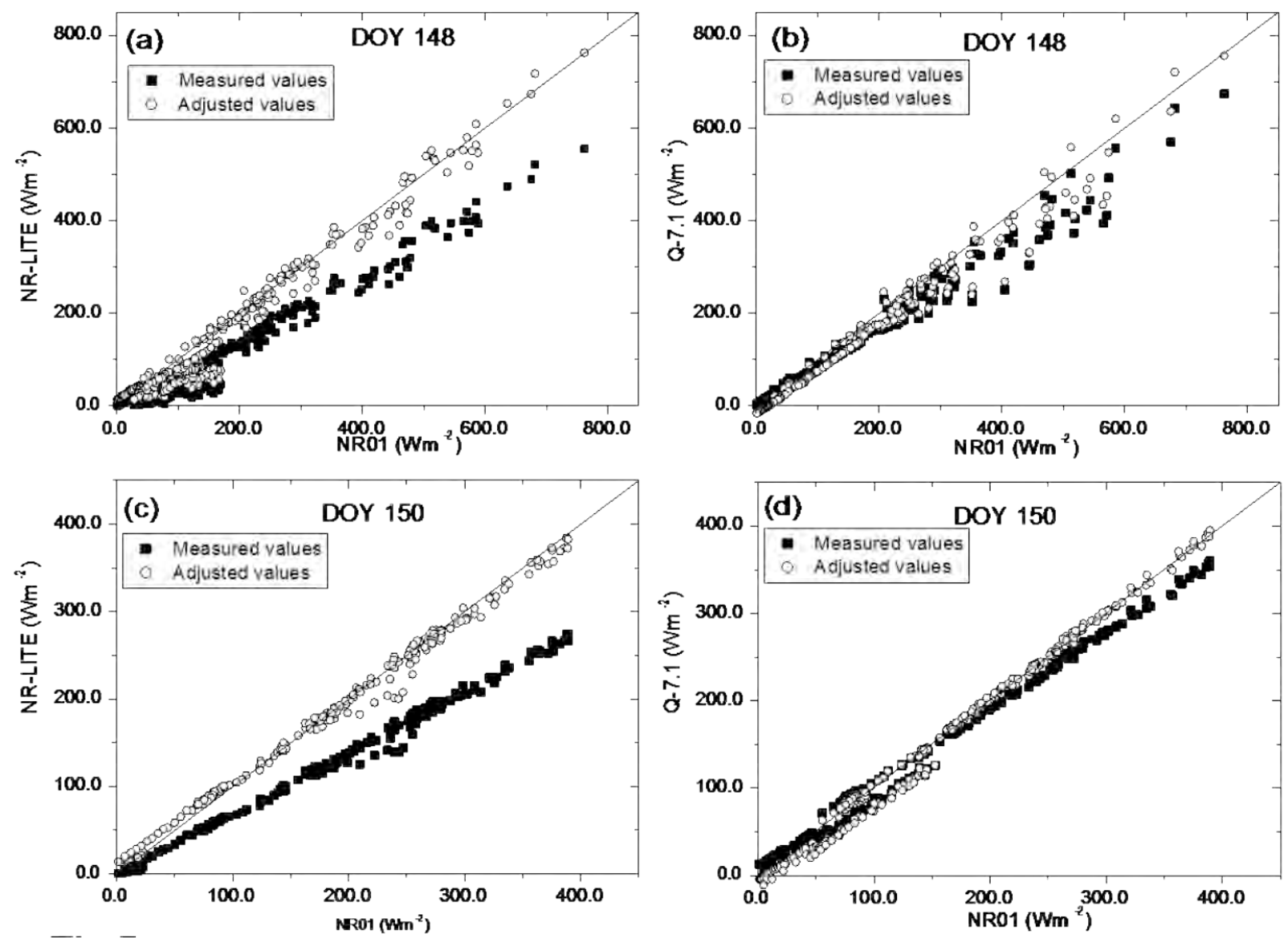

Figure 7: Scatter plots of measured and adjusted values of net radiation for (a) NR-LITE and (b) Q-7.1 net radiometers with NR01 on May 28 $8^{\text {th }}, 2013$ (DOY 148) for daytime. Figures 7 (c) and (d), same as DOY 148, but for DOY 150. 
The net radiation data for May $28^{\text {th }}$ and $30^{\text {th }}, 2013$ (DOY 148 and DOY 150) have been used to validate linear regression both for NR-LITE and Q-7.1 taking with the NR01 measurements separately in Figs. 7 and 8 for daytime $\left(R_{N}>0\right)$ and nighttime $\left(R_{N}<0\right)$ conditions respectively. Using the regression coefficients in Table $5\left(R^{2}\right.$ is 0.913 for NR-LITE and 0.989 for Q-7.1 for the daytime), the scatter plots of the adjusted data are shown in Figs. 7 (a) and (b) for DOY 148. Similarly, the adjusted data for DOY 150 are plotted in Figs. 7(c) and (d). It can be seen that with simple linear regression, the 1:1 correspondence of both NRLITE and Q-7.1 data can be maintained.

\section{CONCLUSIONS}

In this study, performances of two commercially available REBS type net radiometers: models Q7.1 (domed) and NR-LITE (domeless), have been compared against a reference, four-component net radiometer, model NR01 using two-minute average data obtained during the Nigeria Micrometeorological Experiment (NIMEX) at Ile-Ife, Nigeria, between May $27^{\text {th }}$ and June $12^{\text {th }}$, 2013. It was observed that, under daytime conditions, both NR-LITE and Q-7.1 measurements consistently showed good agreements with NR01, but Q-7.1 has better correlation $\left(R^{2}=0.99\right)$ than NR-LITE $\left(R^{2}=0.91\right)$. Also, the departure of Q-7.1 values from benchmark values of NR01 were smaller than those of NR-LITE values, which makes it better. This is indicated by a lower DIFF of $17.09 \mathrm{~W} \mathrm{~m}^{-2}$ between Q-7.1 and NR01 values as compared to $78.11 \mathrm{~W} \mathrm{~m}^{-2}$ obtained between NR-LITE and NR01 values. At nighttime, the DIFF value between NR-LITE and NR01 net radiation measurements were small, $-3.88 \mathrm{~W} \mathrm{~m}^{-2}$, unlike 17.56 W m $\mathrm{W}^{-2}$ obtained for Q-7.1 and NR01. In the same period, NR-LITE net radiometer responded better to longwave radiation than Q-7.1. Adjustments made by linear regression of both NR-LITE and Q-7.1 with NR01 datasets produced better fit for the case studies on DOY 148 and 150. Based on these results, it can be concluded that Q-7.1 net radiometer model performed better than NR-LITE model for daytime measurements of net radiation for a tropical location. Also, with proper recalibration in the field, the two REBS type of net radiometers can be deployed for routine measurements of net radiation because their costs are comparatively the same. However, for long-term operation, the Q7.1 type requires periodic (every 2-3 months) changing of the plastic domes due to ageing and cracking, unlike the NR-LITE. So, the NR-LITE is a preferred option to be adopted by the Weather Services in West African countries for routine measurements of net radiation because it does not require periodic changing of the plastic domes.

\section{ACKNOWLEDGEMENTS}

The Nigeria Micrometeorological Experiments (NIMEX) was funded by the following organisations: International Programmes in the Physical Sciences (IPPS), Uppsala University, Sweden and Alexander von Humboldt Foundation, Germany.

\section{REFERENCES}

Ayoola, M. A., Sunmonu, L. A., Bashiru, M. I. and Jegede, O. O. 2014. Measurements of Net All-wave Radiation at a Tropical Location, Ile-Ife, Nigeria. Atmósfera, 27, 305-315.

Blonquist, J. M., Tanner, B. D., Bugbee, B. 2009. Evaluation of Measurement Accuracy and Comparison of Two new and three traditional net radiometers. Agricultural and Forest Meteorology, 149, 1709-1721.

Brotzge, J. A., Duchon, C. E. 2000. A Field Comparison among a domeless net radiometer, two four-component net radiometers, and a domed net radiometer. J. Atmos. Oceanic Technol., 17, 1569-1582.

Cobos, D. R., Baker, J. M. 2003. Evaluation and Modification of a domeless net radiometer. Agronomy J., 95, 177-183.

Duchon, C. E., Wilk, G. E. 1994. Field Comparisons of Direct and Component Measurements of net radiation under clear skies. J. Appl. Meteorol. 33, 245-251.

Foken, T. 2008a. Micrometeorology. SpringerVerlag, Berlin. 302pp.

Foken, T. 2008b. The Energy Balance Closure Problem: An overview. Ecol. Appl. 18, 1351-1367.

Fritschen, L. J., Fritschen, C. L., 1991. Design and Evaluation of net radiometers. Presented at $7^{\text {th }}$ Symposium on Meteorological 
Observations and Instrumentations, 1318 January 1991. New Orleans, La. 5pp.

Halldin, S. 1991. Comments on "Correction of errors associated with measurements of net all-wave radiation with double-domed radiometers". Boundary-Layer Meteorol., 57, 195-201.

Halldin, S., Lindroth, A. 1992. Errors in net radiometry: Comparison and evaluation of six radiometer designs. J. Atmos. Ocean. Technol. 9, 762-783.

Jegede, O. O. 1998. A Field Study of the Mean Surface Layer Structure in Sub-Saharan West Africa: The pre-monsoon (dry) season. Mausam 48, 361-370.

Jegede, O. O., Mauder, M., Okogbue, E. C., Foken, T., Balogun, E. E., Adedokun, J. A., Oladiran, E. O., Omotosho, J. A., Balogun, A. A., Oladosu, O. R., Sunmonu, L. A., Ayoola, M. A., Aregbesola, T. O., Ogolo, E. O., Nymphas, E. F., Adeniyi, M. O., Olatona, G. I., Ladipo, K. O., Ohamobi, S. I., Gbobaniyi, E. O., Akinlade, G. O. 2004. The Nigeria Micrometeorological Experiment (NIMEX-1): An overview. Ife Journal of Science, 6, 203-206.

Jegede, O. O., Ogolo, E. O., Aregbesola, T. O. 2006. Estimating Net Radiation using routine meteorological data at a tropical location in Nigeria. Int. J. Sust. Energy, 25, 107-115.

Kjaersgaard, J. H., Cuenca, R. H., Martinez-Cob, A., Gavilan, P., Pluborg, F., Mollerup, M., Hansen, S. 2009. Comparison of the Performance of Net radiation Calculation Models. Theor. and App. Climatol., 98, 57-66.

Kohsiek, C., Liebethal, C., Foken, T., Vogt, R., Oncley, S. P., Bernhofer, C., DeBruin, H.
A. R. 2007. The energy balance experiment EBEX-2000. Part III: Behaviour and quality of the radiation measurements. Boundary-Layer Met., 123, 55-75.

Kothe, S., Ahrens, B. 2010. On the radiation budget in regional climate simulations for West Africa. J. Geophy. Res. - Atmos., 115, 1984-2012.

Kustas, W. P., Prueger, J. H., Hipps, L. E., Hatfield, J. L., Meek, D. 1998. Inconsistencies in Net radiation Estimates from use of Several Models of Instruments in a Desert Environment. Agric. Forest Meteorol. 90, 257-263.

Manual for NR01 net radiometer (2008) NR01 Four-Component Net Radiation Sensor, Rev. 11/08, Campbell Scientific, Inc., Logan, Utah, 14 pp.

Manual for NR-LITE net radiometer (2006) NRLITE Net Radiometer, Rev. 8/06, Campbell Scientific, Inc., Logan, Utah, 34 pp.

Manual for Q-7.1 net radiometer (1996) Q-7.1 Net Radiometer, Rev. 5/96, Campbell Scientific, Inc., Logan, Utah, 8 pp.

Offerle, B., Grimmond, C. S. B., Oke, T. R. 2003. Parameterization of Net-all wave radiation for urban areas. Journal of Applied Met., 42, 1157-1173.

Oliver, H. R., Wright, I. R. 1990. Correction of errors associated with measurements of net all-wave radiation with double-domed radiometers. Boundary-Layer Met., 53, 401407.

Samani, Z., Nolin, S., Bleiweiss, M., Skaggs, R. 2005. Discussion of "Predicting daily net radiation using minimum climatological data". Journal of Irrigation and Drainage Engineering, 131, 388-389. 